\title{
Ortaokul Öğrencilerinin Matematik Öğretmenlerinin Güdüsel Desteklerine İlişskin Algıları ile Güdüsel İnançları Arasındaki İlişkiler
}

\author{
The Relationships between Middle School Students' Perceptions Regarding \\ Mathematics Teachers' Motivational Support and their Motivational Beliefs
}

\section{Neşe ÖZKAL* Cengiz ERDÍK**}

Öz: $\mathrm{Bu}$ araştırmanın amacı ortaokul 6., 7. ve 8. sınıf öğrencilerinin Matematik öğretmenlerinin güdüsel desteklerine ilişkin algılarının ve Matematik dersi güdüsel inançlarının sınıf, cinsiyet ve Matematik başarı notlarına göre farklılaşıp farklılaşmadığı ile öğrencilerin Matematik öğretmenlerinin güdüsel desteklerine ilişkin algılarının Matematik dersi güdüsel inançlarını yordama gücünü incelemektir. Çalışma 2013-2014 öğretim yılı ikinci döneminde Antalya ili Alanya ilçesinde 15 okulda, 732 ortaokul öğrencisinin katılımıyla gerçekleştirilmiştir. Araştırma verileri "Öğretmen Güdüsel Desteği” ve "Güdülenme" ölçekleri ile toplanmıştır. Veriler Mann-Whitney U Testi, Kruskal Wallis Testi, Spearman's rho analizi ve Regresyon analizi ile çözümlenmiştir. Araştırma verileri analizi sonucunda kadınların erkeklere, 6. sınıfların 7. ve 8. sınıflara ve başarı notu yüksek olanların düşük olanlara göre Matematik öğretmenlerinin güdüsel desteklerine ilişkin algılarının daha olumlu olduğu belirlenmiştir. Öğrencilerin Matematik dersi güdüsel inançlarının içsel hedef yönelimi, sınav kaygısı ve görev değeri alt boyutlarında kadın öğrencilerin erkeklere göre anlamlı derecede farklılaştığı belirlenmiştir. Öğrencilerin sınav kaygısı dışında sınıf düzeyleri artıkça güdüsel inançlarının düştüğü ve başarı notları yüksek olan öğrencilerin güdülerinin daha yüksek olduğu belirlenmiştir.

Anahtar sözcükler: Matematik, Güdüsel İnançlar, Öğretmen Güdüsel Desteği

Abstract: This study aimed to investigate if middle school $6^{\text {th }}, 7^{\text {th }}$ and $8^{\text {th }}$ grade students perceptions regarding motivational support provided by mathematics teachers and their own motivational beliefs in mathematics classes differ, based upon grade, gender and mathematics achievement scores and, to examine the predictive power of students' perceptions regarding the motivational support provided by mathematics teachers related to motivational beliefs in mathematics. The study was conducted with the participation of 732 secondary school students from 15 schools in the 2013-2014 academic year in the Alanya district of Antalya province. Data was collected through the "Teacher Motivational Support" and "Motivation" scales. The Mann-Whitney U Test, Kruskall Wallis Test, Spearman's rho analysis and regression analysis were employed in the analysis of the data. Based upon this data analysis, perceptions regarding the mathematics teachers' motivational support were found to be higher in females compared to males, in $6^{\text {th }}$ graders, as compared to $7^{\text {th }}$ and $8^{\text {th }}$ graders and in high achievers compared to low achievers. It was also determined that the students' motivational beliefs in mathematics differed significantly for female students, when compared to male students, in intrinsic goal orientation, test anxiety and task value sub dimensions. It was observed that student motivation decreased together with grade levels in all sub dimensions other than test anxiety, and that those students with higher mathematics scores had higher levels of motivation.

Keywords: Mathematics, Motivational Beliefs, Teachers' Motivational Support

\footnotetext{
*Yrd. Doç. Dr. Alanya Alaaddin Keykubat Üniversitesi, Eğitim Fak., İlköğretim Böl., Antalya. neseozkal@gmail.com

** Yrd. Doç. Dr. Alanya Alaaddin Keykubat Üniversitesi, Eğitim Fak., İlköğretim Böl., Antalya. c.erdik@hotmail.com Y1ldız International Conference on Educational Research and Social Studies'de sözlü bildiri olarak sunulmuştur.
} 
Güdülenme davranışı dinamikleştiren/harekete geçiren ve yönlendiren kuvvete işaret eder (Reeve 2009). Öğrenme sürecine güdülü olarak katılmayan öğrencinin başarılı olması çok zordur. Öğrencinin öğrenme sürecine etkin katılımını, bilişsel ve bilişüstü strateji kullanımını etkileyen en önemli faktörlerden birisi de güdüsel inançlarıdır (Üredi \& Üredi 2005). Güdüsel inançlar, öğrencilerin objeler, olaylar ya da konu alanına ilişkin sahip oldukları inançlar, fikirler ve değer yargiları olarak tanımlanabilir (Boekaerts 2002 akt. Üredi \& Üredi 2005). Güdü doğrudan gözlemlenemez, öğrencinin davranışları yoluyla anlaşılabilir. Öğrencilerin güdüsel inançlarını beklenti, değer ve duyuşsal bileşenler etkilemektedir (Büyüköztürk et al. 2004).

Beklenti öğrencilerin akademik bir işi başarıp başaramayacağı hakkındaki inançlarını ifade etmektedir. Beklenti öğrencilerin özyeterlik algılarını ve ögrenme kontrol inançlarını kapsamaktadır (Büyüköztürk et al. 2004). Beklentilerin olumsuz olması güdüyü azaltır (Açıkgöz 2012). Özyeterlik öğrencilerin belli bir bağlam içinde bir işi başarıyla yürütmek için kişinin kendi yeteneklerine olan inancı olarak tanımlanabilir. Özyeterlik öğrencileri duyuşsal, bilişsel ve davranışsal olarak etkiler (Bandura 1994). Öğrencilerin derslere yönelik özyeterlik inançları farklılık gösterir. Türkçe dersine ilişkin özyeterlik inancı yüksek olan bir öğrencinin Matematik dersine yönelik özyeterliği düşük olabilir. Yüksek özyeterlik inancına sahip olan öğrenciler özyeterliği düşük olanlara göre daha azimli, sebatlı ve çabalıdırlar. Dolayısı ile özyeterliğin güdünün devamına önemli bir katkısı vardır. (Zimmerman 2000; Tschannen-Moron \& WoolfolkHoy 2001). Öğrenme kontrol inançlarl genel olarak öğrencinin öğrenme süreci sonunda elde edeceği sonuçlar öğrenme düzeyini olumlu olarak etkilerse daha çok çaba göstereceğini ifade etmektedir (Pintrich 1991 akt. Aktan \& Tezci 2013).

Dĕger ise öğrenenlerin hedefleri ve görevlerinin önemi hakkındaki inanc1 ve ilgisidir. Değer öğrencinin akademik işi yapma nedenine odaklanmaktadır. Değer içsel hedef yönelimi dışsal hedef yönelimi ve iş değerini kapsamaktadır. Hedefler genel olarak davranışın temelindeki amaçları belirleyen inanç, duygu ve yüklemeler olarak tanımlanabilir (Ames 1992). İçsel hedefler (öğrenme hedefleri) ve dişsal hedefler (performans hedefleri) olarak öğrencilerin bilişsel, duyuşsal ve davranışsal tepkilerini etkiler (Elliot 1999; Akın \& Çetin 2007). İçsel hedef yönelimli öğrenciler öğrenmeye içsel olarak güdülüdürler, zorluklar karşısında sebat gösterirler. Diğerleriyle yarışmak yerine kendilerini geliştirmeye odaklıdırlar. Dışsal hedef yönelimliler ise arkadaş, öğretmen, aile gibi dişsal etkenlerden etkilenirler. Hedefleri diğerlerinden daha iyi olmaktır ve öğrenmeye dışsal olarak güdülüdürler (Schunk 1994; Pintrich 1999). Çalışmalar içsel hedef yöneliminin duyuşsal ve bilişsel öğrenme ürünlerini daha olumlu etkilediğini göstermiştir (Örneğin; Çetin \& Akın 2009; Özkal 2013a; Özkal 2013b). İ̧değeri ise öğrenenlerin o işe verdiği önem derecesini ifade etmektedir. Öğrenci verilen ödevi yapmak ya da bilgisayar da oyun oynamak isteyebilir. Öğrencinin davranışını seçimini o ödevin yapması ya da yapmamasının sonucuna verdiği önem belirleyecektir (Açıkgöz 2012).

Duyuş ise öğrencilerin sınavlarla ilgili endişe ve kaygılarını içine alan sınav kaygısını ifade etmektedir. Sınav kaygısı öğrencinin sınava yüklediği anlamlar, sınavla ilgili oluşturulan imaj, sınavın sonucunda elde edilecek kazanımlara verilen önem nedeniyle öğrendiklerini sınav sırasinda kullanmasını engelleyen yoğun kaygı olarak tanımlanabilir. Sınav kaygısı huzursuzluk, endişe, sıkıntı, başarısızlık korkusu gibi duyuşsal ve ağız kuruluğu, karın ağrısı, terleme gibi fiziksel tepkilere neden olabilir. Ayrıca öğrencinin dikkat ve konsantrasyonunda bozulma, güveninde azalma, yetersizlik ve değersizlik duyguları oluşturabilir. Sonuç olarak yoğun kaygı akademik başarının düşmesine neden olabilir (Türk Psikiyatrı Derneği 2015).

Öğrenme sürecinde öğrencilerin içsel hedef yönelimli, iş değeri, öğrenme kontrol inançları ve özyeterliklerinin yüksek olması güdü, başarı, strateji kullanımı gibi öğrenme ürünlerini olumlu olarak etkilemektedir. Dışsal hedef yönelimi ve sınav kaygısı ise olumlu öğrenme ürünleri ile olumsuz ilişkiler göstermektedir. Bu nedenle öğrencilerin belli bir konu bağlamında 
güdüsel inançlarını belirlemek önemlidir. Bu çalışmada öğrencilerin Matematik dersine yönelik güdüsel inançları ele alınmıştır. Matematik dersi öğrenciler tarafından sevilmeyen, sıkıcı ve soyut olarak algılanan bir derstir (Tahiroğlu \& Çakır 2014). Güdüsel inançlar öğrencileri özdüzenlemeli öğrenme stratejilerini kullanmalarına yöneltmekte (Pintrich \& De Groot 1990 akt. Kılıç \& Tanrıseven 2012) ve Matematik başarısını yordamaktadır (Üredi \& Üredi 2005; Kılıç \& Tanrıseven 2012). Türkiye'nin ulusal ve uluslararası Matematik sınav sonuçları oldukça düşüktür. Türkiye TIMSS 2007'de 30. sırada, TIMSS 2011'de katılan 50 ülke içinde 4. sinıflarda 35., 8. sinıflarda ise 24. sıra da yer almıștır (Yücel et al. 2013). 2011 SBS 3,19 ve 2012 SBS 4,39 net ile Matematik tümdersler arasında en düşük düzeyde kalmıştır (MEB 2011; 2012 akt. Şan 2013). Bu sonuçlar akademik başarı ve güdü arasındaki olumlu ilişkiler düşünüldüğünde öğrencilerin Matematik dersine güdülü olmalarının önemini ortaya koymaktadır. Bulut (2006) yaptığı çalışmada 6., 7. ve 8. sınıf öğrencilerinin Matematik başarı güdülerinin orta düzeyde olduğunu belirtmiștir. Araştırma sonuçları güdünün Matematik dersinde başarı, strateji kullanımı, katılım, tutum ile olumlu, kaygı ile olumsuz olarak ilişkili olduğunu göstermiştir (Bulut 2006; Kılıç 2011; Yılmaz 2011).

Öğrencilerin güdüsel inançlarını etkileyen en önemli etkenlerden birisi öğretmendir. Son yıllarda özbelirleme kuramı öğrenci güdülenmesi konusunda işevuruk önerileri ile dikkat çekmektedir (Güvenç \& Güvenç 2014). Özbelirleme kuramı evrensel olarak kabul edilen temel gereksinimlerinin karşılanması ile güdünün sağlanabileceğini öne sürmektedir (Niemic \& Ryan 2009). Bu temel gereksinimler özerklik, yetkinlik ve ilişki olarak belirtilmektedir. Okul bağlamında yetkinlik öğrencilerin akademik etkinliklerde başarılı ve etkili olma gereksinimini, ilişki aidiyet, öğrenme çevresindeki öğretmen, akran ve okula bağlllık gereksinimini, özerklik ise öğrencinin öğrenme etkinliklerinde kendi kararlarını vermesi, kendini özgün hissetmesi gereksinimini ifade etmektedir (Deci et al. 1991). Bu gereksinimler okul bağlamında öğretmen tarafından karşılanmaktadır.

Ders sırasında öğrencilerin ilgilerinin nasıl yüksek tutulacağı kısmen öğrenmenin gerçekleştiği sınıf koşullarının destekleyici niteliğine ve en önemlisi öğretmenin güdüleme biçemine bağlıdır (Reeve 2006). Seniye (2007) yaptığı çalışmada hem öğretmenlerin hem de öğrencilerin, iyi bir öğretmen-öğrenci ilişkisinin ve öğretmenlerin arkadaşça ve destekleyici olmalarının en güdüleyici davranışlar olduğunu düşündüklerini belirtmiştir. Öğretmen ve öğrenci arasında yaşanan olumlu etkileşim öğrencilerin derse ve okula olan ilgilerini destekler. Ayrıca öğrencilerin yeni değerleri içselleştirmesi, önemli beceriler ve sosyal sorumluluk geliştirmesi için bir rehber olarak işlev görür (Reeve 2006).

Öğretmenin güdüleme biçemi öğrencinin özerk güdülenmesini etkiler. Sınıf ortamında özerklik destekleme öğretmenin öğrencilerinin farklı bakış açılarını kabulü, akademik etkinliklerde öğrencilere farklı seçenekler sunması, yapılması mutlaka gerekli olan etkinliklerle ilgili açıklamalar yapması, öğrencilerin duygularına önem vermesi, öğrencinin yeterliliğine ilişkin olumlu dönütler vermesi ile sağlanabilir (Deci et al.1994 akt. Reeve et al. 2013; Niemic \& Ryan 2009). Öğretmenler öğrencilere sınıflarda özerklik destekleyici ya da kontrol edici davranışlar sergilerler. Kontrolcü öğretmenler öğrencilere yapılması gerekli olan talimatlar verirler, daha öğretmen merkezli yöntemler ve dışsal ödüller kullanırlar (Reeve 2006; 2009). Öğrencilerin özerkliklerinin desteklenmesi güdüyü artırır (Jungert \& Koestner, 2015; Vanteenkiste et al. 2012). Kontrol davranışları ise güdüyü azaltır ( Fortier, Vollerand \& Gay 1995).

Türkiye'de de öğretmenlerin öğrencilere özerklik desteği verilmesinin gerekli olduğunu düşündükleri, ancak bu desteklere ilişkin davranışları daha az sergiledikleri (Oğuz 2013; Özkal \& Demirkol 2014) ve öğrencilerine orta düzey özerklik desteği ve orta düzey kontrol desteği sağladıkları görülmektedir (Sünbül, Kesici \& Bozgeyikli 2003; Güvenç 2011; Oğuz 2013). Güvenç \& Güvenç (2014) ilköğretim Matematik öğretmenlerinin özerklik desteğinin orta 
düzeyde olduğunu, Özkal \& Demirkol (2014) sınıf ve ortaokul branş öğretmenleri üzerinde yaptıkları çalışmada Matematik öğretmenlerinin genel olarak en düşük öğrenen özerkliği destekleme davranışlarını sergiledikleri belirlenmiştir.

Güdü ile olumlu öğrenme ürünleri arasında olumlu ilişkiler olduğu, öğretmenin güdüleme biçeminin öğrencilerin güdülenmelerini etkilediği ve Türkiye bağlamında öğretmenlerin özerklik desteklerinin orta düzeyde olduğuna ilişkin araştırma bulguları alanyazında yer almaktadır. Yapılacak olan bu çalışmada ise öğrencilerin Matematik dersi öğretmenlerinin özerklik desteklerininin yanısıra yetkinlik ve ilişki desteklerine ilişkin algılarını da kapsayacaktır. Ayrıca bu çalışma ile Matematik dersine yönelik öğrencilerin güdüsel inançları, Matematik öğretmenlerinden aldıkları güdüsel destekleri ve öğretmen güdüsel desteğinin güdüsel inançlar üzerindeki etkisi belirlenecektir. Çalışmanın mevcut durumun ortaya konmasına, alanyazına, dolaylı olarak öğrencilerin Matematik başarılarına, Matematik dersine güdülenmelerine, hizmet içi ve hizmet öncesi ögretmen yetiştirme programlarına dönük öneriler oluşturmaya katkı sağlayacağı umulmaktadır.

$\mathrm{Bu}$ amaçla aşağıdaki sorulara yanıt aranmıştır:

1. Öğrencilerin Matematik öğretmenlerinin güdüsel desteklerine ilişkin algıları cinsiyetlerine, sınıf ve başarı düzeylerine göre anlamlı farklılıklar göstermekte midir?

2. Öğrencilerin Matematik dersi güdüsel inançları cinsiyetlerine, sınıf ve başarı düzeylerine göre anlamlı farkl11ıklar göstermekte midir?

3. Öğrencilerin Matematik öğretmenlerinin güdüsel desteklerine ilişkin algıları Matematik dersi güdüsel inançlarını yordamakta mıdır?

\section{Yöntem}

\section{Araștırmanın Modeli}

Araştırmada iki ve daha çok sayıda değişken arasında birlikte değişimin varlığı ve/veya derecesini araştıran genel tarama modellerinden ilişkisel tarama modeli kullanılmıştır (Karasar, 2009).

\section{Çalışma Grubu}

Araştırma 2013-2014 öğretim yılında Antalya ili Alanya ilçesinde yer alan ve uygulama izni alınan 15 ortaokulda 6., 7. ve 8. sınıfta öğrenim gören 732 öğrencinin gönüllü katılımıyla gerçekleştirilmiştir. Araştırmaya katılan öğrencilerin \% 55,2'si (n=404) kadın, \% 44,8'i (n=328) erkektir. Öğrencilerin \% 30,5'i $(n=223) 6$. sinıf, \% 37,6'si $(n=275)$ 7., \% 32'si $(n=234)$ 8. sinıfa devam etmektedir.

\section{Veri Toplama Araçları}

Bu araştırmada, araştırma verileri ortaokul 6, 7 ve 8. sınıf öğrencilerine uygulanan "Güdülenme ve Özdüzenleme Ölçeği” (Büyüköztürk et al. 2004) ve "Öğretmen Güdüsel Desteği”" (Güvenç 2015) ile toplanmıştır.

\section{Güdülenme ve Özdüzenleme Ölçeği}

Güdülenme ve Öğrenme Stratejileri Ölçeği (GÖSÖ) Pintrich, Smith, Garcia ve McKeachie tarafindan üniversite öğrencilerin güdülenme ve öğrenme stratejilerini belirlemek üzere geliştirilmiştir (Pintrich et al. 1991 akt. Büyüköztürk et al. 2008). Ölçek 12-18 yaş öğrencileri için Büyüköztürk et al. (2008) tarafından uyarlanmıştır. Ölçek 7'li likert tipinde düzenlenmiş olup, Güdülenme ve Öğrenme Stratejileri ölçeklerinden oluşmaktadır. Bu çalışmada bu ölçeklerden yalnızca güdülenme ölçeği kullanılmıştır. Öğrencilerin belirli bir ders ya da konu alanındaki güdü kaynaklarını ölçmeye yönelik olarak geliştirilen ölçme aracı, bu çalışmada Matematik dersine yönelik olarak kullanılmıştır. Güdülenme ölçeğinin uyarlama çalışmasında da ölçeğin yedi 
alt faktörden oluştuğu belirlenmiş, alt faktörlerin Cronbach Alpha Güvenirlik Katsayıları İçsel hedef düzenleme ,75, Dişsal hedef düzenleme ,56, Görev değeri ,83 ve öğrenmeye ilişkin kontrol inanc1 ,63, Öğrenme ve performansla ilgili öz yeterlik ,86, Sınav kaygısı ,56 ve ölçeğin tümü için ,90, olarak hesaplanmıştır.

\section{Öğretmen Güdüsel Desteği Ölçeği}

Öğretmen güdüsel desteği ölçeği Güvenç (2015) tarafindan öğrencilerin öğretmenlerinin güdüsel desteklerine ilişkin özbelirleme temelli algılarını belirlemek için geliştirilmiştir. Ölçek 4'lü likert tipi 3 alt ölçek ve 24 maddeden oluşmaktadır. Ölçeğin hem lise hem de ortaokul öğrencileri üzerinde geçerlik ve güvenirlik analizleri yapılmıştır. Bu çalışmada ortaokul öğrencilerinin Matematik öğretmenlerinin güdüsel desteklerine ilişkin algıları ölçmek amacıyla kullanılmıştır. Ölçeğin ortaokul öğrencileri için alt faktörlerinin Cronbach Alpha Güvenirlik Katsayıları Aidiyet desteği,77, Özerklik desteği ,87, Yeterlik desteği ,81 ve ölçeğin tümü için ,92'dür. Ölçeğin doğrulayıcı faktör analizi sonucu ise Ki Kare $\left(\chi^{2}=537.09\right)$, serbestlik derecesi $(\mathrm{df}=249, \mathrm{p}=0.00)$ oranının $\chi^{2} / \mathrm{df}=2.16$; RMSEA $=0,079 ; \mathrm{SRMR}=.053$, $\mathrm{AGFI}=.84 ; \mathrm{CFI}=.90 ; \mathrm{GFI}=.91 ; \mathrm{NNFI}=.85$ olarak hesaplanmıştır.

\section{Veri Analizi}

Araştırmada öncelikle elde edilen verilerin dağılımı incelenmiştir. Çalışma grubundan elde edilen verilerin normal dağılım gösterip göstermediğini test etmek amacıyla uygulanan Kolmogorov-Smirnov ve Shapiro-Wilks Testi sonuçları dağılımın normal olmadığını göstermiştir. Bu nedenle çalışmada parametrik olmayan testler kullanılmıştır. Bağımsız gruplar için elde edilen puanların birbirinden anlamlı bir şekilde farklılık gösterip göstermediğini test etmek için MannWhitney U-Testi kullanılmıştır. İki ya da daha çok grubun bir bağımlı değişkene ait ortalamaları arasında anlamlı bir farklılık olup olmadığını tespit etmek için Kruskal-Wallis Testi ve Spearman korelasyon katsayısı ve öğretmen güdüsel desteğinin Matematik dersine güdüsel inançlarını yordayıp yordamadığı belirlemek içinde regresyon analizi yapılmıştır.

\section{Bulgular}

Öğrencilerin Matematik öğretmenlerinin güdüsel desteklerine ilişkin algılarının cinsiyetlerine göre anlamlı farklılıklar gösterip göstermediğini belirlemek için kadın ve erkek öğrencilerin ölçekten aldıkları puanların sıra ortalamaları ve toplamları hesaplanmış ve Mann-Whitney UTesti uygulanmıştır. İlgili sonuçlar Tablo 1'de sunulmuştur. Tablo 1'de görüldüğg̈ gibi, kadın öğrencilerin Matematik öğretmenlerinin güdüsel desteklerine ilişkin algılarına ilişkin puanları sıra ortalamaları ve toplamları erkek öğrencilerin puanlarından yüksektir. Mann-Whitney UTesti sonuçları öğrencilerin öğretmen güdüsel desteğine ilişkin algıları Aidiyet desteği $[U(732)=$ $54939,0 ; \mathrm{p}<, 01)]$; Özerklik desteği $[\mathrm{U}(732)=55279,5 ; \mathrm{p}<, 01]$; Yeterlik desteği $[\mathrm{U}(732)=$ $53433,5 ; \mathrm{p}<, 01]$ alt boyutlarında ve toplam puanda $[\mathrm{U}(732)=53129,0 ; \mathrm{p}<, 01]$, kadın öğrenciler lehine anlamlı bir şekilde farklılık olduğunu göstermektedir.

Tablo 1. Öğrencilerin cinsiyetlerine göre Matematik öğretmenlerinin güdüsel desteklerine ilişkin algıları Mann-Whitney U-Testi sonuçları

\begin{tabular}{|c|c|c|c|c|c|c|}
\hline Alt Boyutlar & Cinsiyet & $\mathrm{n}$ & Sira Ortalaması & Sira Toplamı & $\mathrm{z}$ & $\mathrm{p}$ \\
\hline & Kadın & 404 & 394,5 & 159383,0 & $-3,98$ & \\
\hline \multirow{2}{*}{ Aidiyet } & Erkek & 328 & 332,0 & 108895,0 & &, $00 *$ \\
\hline \multirow{2}{*}{ Özerklik } & Kadın & 404 & 398,9 & 161193,0 & & \\
\hline \multirow{3}{*}{ Yeterlik } & Erkek & 328 & 326,4 & 107085,0 & $-4,61$ &, $00 *$ \\
\hline
\end{tabular}




\begin{tabular}{|c|c|c|c|c|c|c|}
\hline & Kadın & 404 & 398,9 & 161193,0 & & \\
Toplam & Erkek & 328 & 326,4 & 107085,0 & $-4,61$ &, $00 *$ \\
\hline
\end{tabular}

Öğrencilerin Matematik öğretmenlerinin güdüsel desteklerine ilişkin algılarının sınıf düzeyine göre anlamlı farklılıklar gösterip göstermediğini belirlemek için 6., 7. ve 8. sinıf öğrencilerinin ölçekten aldıkları puanların sıra ortalamaları hesaplanmış ve Kruskal-Wallis Testi uygulanmıştır. İlgili sonuçlar Tablo 2'de sunulmuştur.

Tablo 2. Öğrencilerin sınıf düzeyine göre Matematik öğretmenlerinin güdüsel desteklerine ilişkin algıları Kruskal-Wallis Testi sonuçları

\begin{tabular}{|c|c|c|c|c|c|c|}
\hline Alt Boyutlar & Sinif & $\mathrm{n}$ & Sira Ortalaması & $X^{2}$ & $\mathrm{p}$ & $\begin{array}{c}\text { Anlamlı } \\
\text { Fark }\end{array}$ \\
\hline \multirow[b]{3}{*}{ Aidiyet } & 6 & 223 & 428,1 & & & \\
\hline & 7 & 275 & 359,2 & & & \\
\hline & 8 & 234 & 316,2 & 32,6 &, $00 *$ & $6>7>8$ \\
\hline \multirow[b]{3}{*}{ Özerklik } & 6 & 223 & 420,2 & & & \\
\hline & 7 & 275 & 367,3 & & & \\
\hline & 8 & 234 & 314,2 & 28,9 &, $00^{*}$ & $6>7>8$ \\
\hline \multirow[b]{3}{*}{ Yeterlik } & 6 & 223 & 422,8 & & & \\
\hline & 7 & 275 & 364,5 & & & \\
\hline & 8 & 234 & 315,0 & 29,7 &, $00^{*}$ & $6>7>8$ \\
\hline \multirow[b]{3}{*}{ Toplam } & 6 & 223 & 427,7 & & & \\
\hline & 7 & 275 & 363,9 & & & \\
\hline & 8 & 234 & 311,1 & 34,7 &, $00 *$ & $6>7>8$ \\
\hline
\end{tabular}

Tablo 2 incelendiğinde 6. sınıfta öğrenim gören öğrencilerin Matematik öğretmenlerinin güdüsel destekleri algılarına ilişkin puanları sıra ortalamaları tüm alt boyutlarda ve toplamda en yüksek puana, 8. sınıfların ise en düşük puana sahip olduğu görülmektedir. Bir başka ifadeyle sınıf düzeyi yükseldikçe öğrencilerin öğretmen güdüsel desteğine ilişkin algıları azalmaktadır. Kruskal-Wallis Testi sonuçları öğrencilerin Matematik öğretmenlerinin güdüsel destekleri algılarına ilişkin puanlarının Aidiyet $[X 2(732,2)=32,6$ p $<, 01)]$, Özerklik [X2 $(730)=28,9$ $\mathrm{p}<, 01)$ ], Yeterlik $[\mathrm{X} 2(730)=29,7 \mathrm{p}<, 01)]$, alt boyutlarında ve toplamda $[\mathrm{X} 2(730)=34,7 \mathrm{p}<, 01)]$, anlamlı farkın olduğunu göstermektedir. Gözlemlenen anlamlı farklılaşmanın kaynağını belirlemek amaciyla yapılan Mann-Whitney U-Testi sonucunda tüm alt boyutlarda 6. siniflarla 7. ve 8 . sinıflar arasinda 6. siniflar lehine, 7. siniflarla 8. siniflar arasinda 7. siniflar lehine anlamlı bir farklılaşmanın olduğu saptanmıştır.

Öğrencilerin Matematik öğretmenlerinin güdüsel desteklerine ilişkin algılarının başarı düzeylerine göre anlamlı farklılıklar gösterip göstermediğini belirlemek için öğrencilerinin ölçekten aldıkları puanların sıra ortalamaları hesaplanmış ve Kruskal-Wallis Testi uygulanmıştır. İlgili sonuçlar Tablo 3'de sunulmuştur. Tablo 3 incelendiğinde öğrencilerin başarı düzeylerine göre Matematik öğretmenlerinin güdüsel destekleri algılarına ilişkin puanları sıra ortalamaları incelendiğinde tüm alt boyutlarda ve toplamda öğrencilerin notları düştükçe öğretmen güdüsel destekleri algılarınında düştüğü görülmektedir. Kruskal -Wallis Testi sonuçları öğrencilerin Matematik öğretmenlerinin güdüsel destekleri algılarına ilişkin puanlarının Aidiyet [X2 $(732,4)=86,9 \mathrm{p}<, 01)]$, Özerklik [X2 $(732,4)=76,6 \mathrm{p}<, 01)]$, Yeterlik $[\mathrm{X} 2(732,4)=76,5 \mathrm{p}<, 01)]$, alt boyutlarında ve toplamda $[\mathrm{X} 2(732,4)=96,0 \mathrm{p}<, 01)]$, anlamlı farkın olduğunu göstermektedir. Gözlemlenen anlamlı farklılaşmanın kaynağını belirlemek amacıyla yapılan Mann-Whitney UTesti sonucunda, öğrencilerin Matematik öğretmenlerinden aldıkları güdüsel desteklerinin notları yüksek olanların lehine tüm alt boyutlarda ve toplamda anlamlı bir farklılaşmanın olduğu 
saptanmıştır.

Tablo 3. Öğrencilerin akademik başarılarına göre Matematik öğretmenlerinin güdüsel desteklerine ilişkin algıları Kruskal-Wallis Testi sonuçları

\begin{tabular}{|c|c|c|c|c|c|c|}
\hline Alt Boyutlar & Başarı & $\mathrm{n}$ & Sira Ortalamas 1 & $X^{2}$ & $\mathrm{p}$ & Anlamlı Fark \\
\hline Aidiyet & $\begin{array}{l}1 \\
2 \\
3 \\
4 \\
5\end{array}$ & $\begin{array}{c}54 \\
146 \\
165 \\
169 \\
195\end{array}$ & $\begin{array}{l}250,0 \\
276,9 \\
333,1 \\
409,0 \\
451,4\end{array}$ & 86,09 &, $00^{*}$ & $\begin{array}{c}3>1,3>2 \\
4>1,4>2,4>3 \\
5>1,5>2,5>3,5>4\end{array}$ \\
\hline Özerklik & $\begin{array}{l}1 \\
2 \\
3 \\
4 \\
5\end{array}$ & $\begin{array}{c}54 \\
146 \\
165 \\
169 \\
195\end{array}$ & $\begin{array}{l}241,5 \\
285,0 \\
338,3 \\
411,8 \\
441,0\end{array}$ & 76,6 &, $00^{*}$ & $\begin{array}{c}3>1,3>2 \\
4>1,4>2,4>3 \\
5>1,5>2,5>3\end{array}$ \\
\hline Yeterlik & $\begin{array}{l}1 \\
2 \\
3 \\
4 \\
5\end{array}$ & $\begin{array}{c}54 \\
146 \\
165 \\
169 \\
195\end{array}$ & $\begin{array}{l}236,6 \\
388,6 \\
337,9 \\
406,8 \\
444,4\end{array}$ & 76,5 &, $00^{*}$ & $\begin{array}{c}3>1,3>2 \\
4>1,4>2,4>3 \\
5>1,5>2,5>3,5>4\end{array}$ \\
\hline Toplam & $\begin{array}{l}1 \\
2 \\
3 \\
4 \\
5\end{array}$ & $\begin{array}{c}54 \\
146 \\
165 \\
169 \\
195\end{array}$ & $\begin{array}{l}236,3 \\
273,2 \\
332,6 \\
413,8 \\
454,4\end{array}$ & 96,0 &, $00^{*}$ & $\begin{array}{c}2>1 \\
3>1,3>2 \\
4>1,4>2,4>3 \\
5>1,5>2,5>3,5>4\end{array}$ \\
\hline
\end{tabular}

Öğrencilerin Matematik dersi güdüsel inançlarının cinsiyetlerine göre anlamlı farklılıklar gösterip göstermediğini belirlemek için kadın ve erkek öğrencilerin ölçekten aldıkları puanların sıra ortalamaları ve toplamları hesaplanmış ve Mann-Whitney U-Testi uygulanmıştır. İlgili sonuçlar Tablo 4'de sunulmuştur. Tablo 4'de görüldüğü gibi, kadın öğrencilerin tüm alt boyutlarda Matematik dersi güdüsel inançları sıra ortalamaları ve toplamları erkek öğrencilerin puanlarından yüksektir. Mann-Whitney U-Testi sonuçları öğrencilerin Matematik dersi güdüsel inançlarının İçsel hedef düzenleme $[\mathrm{U}(732)=59780,0 ; \mathrm{p}<, 05)]$; Görev değeri $[\mathrm{U}(732)=58687,5 ; \mathrm{p}<, 01]$; Sinav kaygıs1 $[\mathrm{U}(732)=57280,5 ; \mathrm{p}<, 01]$ alt boyutlarında kadın öğrenciler lehine anlamlı bir şekilde farkl11ık olduğunu göstermektedir.

Tablo 4. Öğrencilerin cinsiyetlerine göre Matematik dersi güdüsel inançları Mann-Whitney U Testi sonuçları

\begin{tabular}{|c|c|c|c|c|c|c|}
\hline Alt Boyutlar & Cinsiyet & $\mathrm{n}$ & Sira Ortalaması & Sira Toplamı & $\mathrm{z}$ & $\mathrm{p}$ \\
\hline \multirow{2}{*}{ İçsel hedef düzenleme } & Kadın & 404 & 382,5 & 154542,0 & 2,28 & $02^{*}$ \\
& Erkek & 328 & 346,7 & 113736,0 & & \\
\hline \multirow{2}{*}{ Dışsal hedef düzenleme } & Kadın & 404 & 373,7 & 150994,5 & $-1,05$ &, 30 \\
& Erkek & 328 & 357,7 & 117283,5 & & \\
\hline \multirow{2}{*}{ Görev Değeri } & Kadın & 404 & 385,2 & 155634,5 & $-2,66$ &, $00^{*}$ \\
& Erkek & 328 & 343,4 & 112643,5 & &, 13 \\
\hline \multirow{2}{*}{ Öğrenme Kontrol İnancı } & Kadın & 404 & 377,1 & 152352,5 & $-1,51$ &, $00 *$ \\
\hline
\end{tabular}




\begin{tabular}{|c|c|c|c|c|c|c|}
\hline & Erkek & 328 & 339,1 & 111236,5 & & \\
\hline Öğrenme ve performansla & Kadın & 404 & 369,3 & 149212,0 & \multirow{2}{*}{-.40} & \multirow{2}{*}{, 68} \\
\hline ilgili öz yeterlik & Erkek & 328 & 363,0 & 119066,0 & & \\
\hline
\end{tabular}

Öğrencilerin Matematik dersi güdüsel inançlarının sınıf düzeyine göre anlamlı farklılıklar gösterip göstermediğini belirlemek için $6 ., 7$. ve 8 . sinıf öğrencilerinin ölçekten aldıkları puanların sıra ortalamaları hesaplanmış ve Kruskal-Wallis Testi uygulanmıştır. İlgili sonuçlar Tablo 5'te sunulmuştur.

Tablo 5. Öğrencilerin sınıf düzeyine göre Matematik dersi güdüsel inançları Kruskal-Wallis Testi sonuçları

\begin{tabular}{|c|c|c|c|c|c|c|}
\hline Alt Boyutlar & Sinif & $\mathrm{n}$ & Sira Ortalaması & $X^{2}$ & $\mathrm{p}$ & $\begin{array}{c}\text { Anlaml1 } \\
\text { Fark }\end{array}$ \\
\hline İçsel hedef düzenleme & $\begin{array}{l}6 \\
7 \\
8\end{array}$ & $\begin{array}{l}223 \\
275 \\
234\end{array}$ & $\begin{array}{l}439,2 \\
381,0 \\
280,0\end{array}$ & 67,02 & $00^{*}$ & $6>7>8$ \\
\hline Dışsal hedef düzenleme & $\begin{array}{l}6 \\
7 \\
8\end{array}$ & $\begin{array}{l}223 \\
275 \\
234\end{array}$ & $\begin{array}{l}411,4 \\
365,6 \\
324,6\end{array}$ & 19,41 &, $00 *$ & $6>7>8$ \\
\hline Görev Değeri & $\begin{array}{l}6 \\
7 \\
8\end{array}$ & $\begin{array}{l}223 \\
275 \\
234\end{array}$ & $\begin{array}{l}452,0 \\
365,9 \\
285,6\end{array}$ & 70,96 &, $00^{*}$ & $6>7>8$ \\
\hline Öğrenme Kontrol İnancı & $\begin{array}{l}6 \\
7 \\
8\end{array}$ & $\begin{array}{l}223 \\
275 \\
234\end{array}$ & $\begin{array}{l}447,8 \\
362,3 \\
293,8\end{array}$ & 61,21 &, $00^{*}$ & $6>7>8$ \\
\hline Sinav Kaygisı & $\begin{array}{l}6 \\
7 \\
8\end{array}$ & $\begin{array}{l}223 \\
275 \\
234\end{array}$ & $\begin{array}{l}388,2 \\
362,3 \\
350,6\end{array}$ & 3,79 &, 15 & \\
\hline $\begin{array}{c}\text { Öğrenme ve performansla ilgili } \\
\text { öz yeterlik }\end{array}$ & $\begin{array}{l}6 \\
7 \\
8\end{array}$ & $\begin{array}{l}223 \\
275 \\
234\end{array}$ & $\begin{array}{l}433,7 \\
381,6 \\
284,5\end{array}$ & 59,21 &, $00^{*}$ & $6>7>8$ \\
\hline
\end{tabular}

Tablo 5 incelendiğinde Matematik dersi güdüsel inançlarına ilişkin puanları sıra ortalamaları tüm alt boyutlarda ve toplamda 6 . sinıfta öğrenim gören öğrencilerin en yüksek puana, 8. s1nıfların ise en düşük puana sahip olduğu görülmektedir. Bir başka ifadeyle sınıf düzeyi yükseldikçe öğrencilerin Matematik dersine ilişkin güdüleri azalmaktadır. Kruskal- Wallis Testi sonuçları öğrencilerin sınıf düzeylerine göre Matematik güdüsel inançlarının İçsel hedef düzenleme $[X 2(732,2)=67,02 \mathrm{p}<, 01)]$, D1şsal hedef düzenleme Özerklik [X2 $(732,2)=19,41 \mathrm{p}<, 01)]$, Görev değeri $[\mathrm{X} 2(732,2)=70,96 \mathrm{p}<, 01)]$, Öğrenme kontrol inanc1[X2 $(732,2)=61,21 \mathrm{p}<, 01)]$, Öğrenme ve performansla ilgili öz yeterlik $[X 2(732,2)=59,21 \mathrm{p}<, 01)]$, alt boyutlarında farkın anlamlı olduğunu göstermektedir. Sınav kaygıs1 [X2 $(732,2)=3,79 \mathrm{p}>, 05)]$ alt boyutunda ise anlamlı bir farklılık yoktur. Gözlemlenen anlamlı farklılaşmanın kaynağını belirlemek amacıyla yapılan Mann- Whitney U-Testi sonucunda 6. siniflarla 7. ve 8. siniflar arasinda 6. siniflar lehine, 7. sinıflarla 8. sınıflar arasında 7. sınıflar lehine anlamlı bir farklılaşmanın olduğu saptanmiştır.

Öğrencilerin Matematik dersi güdüsel inançlarının akademik başarılarına göre anlamlı farklılıklar gösterip göstermediğini belirlemek için öğrencilerinin ölçekten aldıkları puanların sıra ortalamaları hesaplanmış ve Kruskal-Wallis Testi uygulanmıştır. İlgili sonuçlar Tablo 6'da sunulmuştur. Tablo 6 incelendiğinde öğrencilerin güdüsel inançlarının puanları sıra ortalamaları 
incelendiğinde tüm alt boyutlarda ve toplamda öğrencilerin Matematik notları düştükçe derse yönelik güdülerinin de düştüğü görülmektedir. Kruskal-Wallis Testi sonuçları öğrencilerin Matematik güdüsel inançlarının İçsel hedef düzenleme [X2 $(732,4)=71,5 \mathrm{p}<, 01)]$, D1şsal hedef düzenleme Özerklik $[X 2(732,4)=24,1 \mathrm{p}<, 01)]$, Görev değeri $[X 2 \quad(732,4)=102,2 \mathrm{p}<, 01)]$, Öğrenme kontrol inancı[X2 $(732,4)=58,8$ p $<, 01)]$, Öğrenme ve performansla ilgili öz yeterlik $[X 2(732,4)=161,79 p<, 01)]$, alt boyutlarında farkın anlamlı olduğunu göstermektedir. Sınav kaygıs1 [X2 $(732,4)=7,67$ p>,05)] alt boyutunda ise anlamlı bir farkl1lık yoktur. Gözlemlenen anlamlı farklılaşmanın kaynağını belirlemek amacıyla yapılan Mann-Whitney U-Testi sonucunda, öğrencilerin güdü düzeylerinin notları yüksek olanların lehine anlamlı bir farklılaşmanın olduğu saptanmıştır.

Tablo 6. Öğrencilerin akademik başarılarına göre Matematik dersi güdüsel inançları Kruskal- Wallis Testi sonuçları

\begin{tabular}{|c|c|c|c|c|c|c|}
\hline Alt Boyutlar & Başarı & $\mathrm{n}$ & Sira Ortalaması & $\mathrm{X}^{2}$ & $\mathrm{p}$ & Anlamlı Fark \\
\hline \multirow{5}{*}{ İçsel hedef düzenleme } & 1 & 54 & 262,7 & \multirow{5}{*}{71,5} & \multirow{5}{*}{, $00^{*}$} & \multirow{5}{*}{$\begin{array}{c}3>1,3>2 \\
4>1,4>2,4>3 \\
5>1,5>2,5>3,5>4\end{array}$} \\
\hline & 2 & 146 & 295,3 & & & \\
\hline & 3 & 165 & 335,3 & & & \\
\hline & 4 & 169 & 378,6 & & & \\
\hline & 5 & 195 & 458,6 & & & \\
\hline \multirow{5}{*}{ Dışsal hedef düzenleme } & 1 & 54 & 271,6 & \multirow{5}{*}{24,1} & \multirow{5}{*}{, $00^{*}$} & \multirow{5}{*}{$\begin{array}{c}3>1,3>2 \\
4>1,4>2 \\
5>1,5>2,5>3\end{array}$} \\
\hline & 2 & 146 & 325,6 & & & \\
\hline & 3 & 165 & 361,7 & & & \\
\hline & 4 & 169 & 395,1 & & & \\
\hline & 5 & 195 & 397,2 & & & \\
\hline \multirow{5}{*}{ Görev Değeri } & 1 & 54 & 245,2 & \multirow{5}{*}{102,2} & \multirow{5}{*}{, $00 *$} & \multirow{5}{*}{$\begin{array}{c}3>1,3>2 \\
4>1,4>2,4>3 \\
5>1,5>2,5>3,5>4\end{array}$} \\
\hline & 2 & 146 & 279,9 & & & \\
\hline & 3 & 165 & 322,9 & & & \\
\hline & 4 & 169 & 393,6 & & & \\
\hline & 5 & 195 & 472,5 & & & \\
\hline \multirow{5}{*}{ Öğrenme Kontrol İnancı } & 1 & 54 & 261,1 & \multirow{5}{*}{58,8} & \multirow{5}{*}{, $00 *$} & \multirow{5}{*}{$\begin{array}{c}3>1,3>2 \\
4>1,4>2,4>3 \\
5>1,5>2,5>3,5>4\end{array}$} \\
\hline & 2 & 146 & 297,2 & & & \\
\hline & 3 & 165 & 347,0 & & & \\
\hline & 4 & 169 & 392,4 & & & \\
\hline & 5 & 195 & 435,8 & & & \\
\hline \multirow{5}{*}{ Sinav Kaygisı } & 1 & 54 & 349,2 & \multirow{5}{*}{7,67} & \multirow{5}{*}{, 10} & \multirow{5}{*}{-} \\
\hline & 2 & 146 & 346,9 & & & \\
\hline & 3 & 165 & 385,2 & & & \\
\hline & 4 & 169 & 391,2 & & & \\
\hline & 5 & 195 & 343,0 & & & \\
\hline \multirow{5}{*}{$\begin{array}{l}\text { Öğrenme ve performansla } \\
\text { ilgili öz yeterlik }\end{array}$} & 1 & 54 & 224,9 & \multirow{5}{*}{161,79} & \multirow{5}{*}{, $00 *$} & \multirow{5}{*}{$\begin{array}{c}3>1,3>2 \\
4>1,4>2,4>3 \\
5>1,5>2,5>3,5>4\end{array}$} \\
\hline & 2 & 146 & 266,6 & & & \\
\hline & 3 & 165 & 311,0 & & & \\
\hline & 4 & 169 & 378,4 & & & \\
\hline & 5 & 195 & 511,3 & & & \\
\hline
\end{tabular}

Ortaokul 6., 7. ve 8. sınıf öğrencilerinin Matematik öğretmenlerinin güdüsel desteklerine ilişkin algılarının Matematik dersi güdüsel inançları ile ilişkisini incelemek için korelasyon katsayıları hesaplanmış ve Tablo 7'de sunulmuştur. 
Tablo 7. Matematik öğretmenlerinin güdüsel desteklerine ilişkin algıları ile Matematik dersi güdüsel inançları arasındaki Sperman rho Korelasyon Katsayıları

\begin{tabular}{|c|c|c|c|c|c|c|c|c|c|}
\hline & 1 & 2 & 3 & 4 & 5 & 6 & 7 & 8 & 9 \\
\hline Aidiyet & 1 & & & & & & & & \\
\hline Yeterlik &, $75^{*}$ & & & & & & & & \\
\hline Özerklik &, $77^{*}$ &, $78^{*}$ & & & & & & & \\
\hline İçsel hedef düzenleme &, $49^{*}$ &, $49^{*}$ &, $50^{*}$ & & & & & & \\
\hline Dişsal hedef düzenleme &, $17^{*}$ &, $21^{*}$ &, $22^{*}$ &, $42^{*}$ & & & & & \\
\hline Görev değeri &, $57^{*}$ &, $55^{*}$ &, $56^{*}$ &, $77^{*}$ &, $41^{*}$ & & & & \\
\hline Öğrenme kontrol inancı &, $44^{*}$ &, $48^{*}$ &, $46^{*}$ &, $61^{*}$ &, $37^{*}$ &, $65^{*}$ & & & \\
\hline Özyeterlik &, $52^{*}$ &, $54^{*}$ &, $52^{*}$ &, $72^{*}$ &, $38^{*}$ &, $77^{*}$ &, $61^{*}$ & & \\
\hline Sinav kaygıs1 &, 05 &, 06 &, $12^{*}$ &, $22^{*}$ &, $29^{*}$ &, $14^{*}$ &, $25^{*}$ &, 07 & 1 \\
\hline
\end{tabular}

Tablo 7'de görüldüğü gibi öğrencilerin Matematik öğretmenlerinin güdüsel desteklerine ilișkin algıları ile Matematik dersi güdüsel inançları arasında Sınav kaygısı ve Dıșsal hedef düzenleme boyutları dışında bütün boyutlarda pozitif yönde orta düzeyde önemli ilişki olduğu bulunmuştur.

Öğrencilerin Matematik öğretmenlerinin güdüsel desteklerine ilişkin algılarının Matematik dersi güdüsel inançlarını yordama gücünü test etmek için regresyon analizi yapılmış ve sonuçlar Tablo 8'de verilmiştir. Tablo 8 incelendiğinde öğrencilerin Matematik öğretmenlerinin güdüsel desteklerine ilişkin algılarının öğrencilerin güdüsel inançlarının İçsel hedef düzenleme $[F(3,728)=101,07 \mathrm{p}<, 01]$, Dişsal hedef düzenleme $[\mathrm{F}(3,728)=19,04 \mathrm{p}<, 01]$, Görev Değeri $[\mathrm{F}(3,728)=150,46, \mathrm{p}<.01]$, Öğrenme kontrol inanc1[F(3,728)=96,23, $\mathrm{p}<.01]$, Sinav Kaygis1 $[F(3,728)=7,49, p<.01]$ ve Öğrenme ve performansla ilgili öz yeterlik $[F(3,728)=126,19$, $\mathrm{p}<.01]$ yordayabildiği görülmektedir. Bağımsız değişkenler birlikte, öğrencilerin güdüsel desteklerine ilişkin algılarının İçsel hedef düzenleme varyansının \%29'unu, Dışsal Hedef Düzenleme varyansının \%,07'sini, Görev Değeri varyansının \% 38'ini, Öğrenme kontrol inancı varyansının \%28'ini, Sınav Kaygısı varyansının \% 03'ünü ve Öğrenme ve performansla ilgili öz yeterlik varyansının \% 34'ünü açıklayabilmektedirler. Regresyon katsayılarının anlamlılığına ilişkin t-Testi sonuçları incelendiğinde, öğrencilerin Matematik öğretmenlerinden algıladıkları Aidiyet desteğinin öğrencilerin İçsel hedef düzenlemelerinin $[(\beta=, 17, p<, 01), t(3,728)=3,18$, $\mathrm{p}<.01]$, Görev değeri $[(\beta=, 19, \mathrm{p}<.01), \mathrm{t}(3,728)=3,89, \mathrm{p}<, 01]$, Öğrenme kontrol inanc1 $[(\beta=, 10$, $\mathrm{p}<.01), \mathrm{t}(3,728)=2,01, \mathrm{p}<, 01]$ ve Öğrenme ve performansla ilgili öz yeterlik $[(\beta=, 19, \mathrm{p}<.01)$, $\mathrm{t}(3,728)=3,81, \mathrm{p}<.01]$ önemli yordayıcısı olduğu görülmektedir.

Öğrencilerin Matematik öğretmenlerinden algıladıkları Yeterlik desteğinin öğrencilerin İçsel hedef düzenlemelerinin $[(\beta=, 18, \mathrm{p}<, 01), \mathrm{t}(3,728)=3,20, \mathrm{p}<.01]$, Görev değeri $[(\beta=, 23$, $\mathrm{p}<.01), \mathrm{t}(3,728)=4,42, \mathrm{p}<, 01]$, Öğrenme kontrol inanc1 $[(\beta=, 23, \mathrm{p}<.01), \mathrm{t}(3,728)=4,01$, $\mathrm{p}<, 01]$ ve Öğrenme ve performansla ilgili öz yeterlik $[(\beta=, 30, \mathrm{p}<.01), \mathrm{t}(3,728)=5,42, \mathrm{p}<.01]$ önemli yordayıcısı olduğu görülmektedir.

Öğrencilerin Matematik öğretmenlerinden algıladıkları Özerklik desteğinin öğrencilerin İçsel hedef düzenlemelerinin $[(\beta=, 22, \mathrm{p}<, 01), \mathrm{t}(3,728)=3,81, \mathrm{p}<.01]$, Dişsal hedef düzenleme $[(\beta=, 25, \mathrm{p}<, 01), \mathrm{t}(3,728)=3,80, \mathrm{p}<.01]$, Görev değeri $[(\beta=, 25, \mathrm{p}<.01), \mathrm{t}(3,728)=4,15, \mathrm{p}<, 01]$, Öğrenme kontrol inanc1 $[(\beta=, 22, \mathrm{p}<.01), \mathrm{t}(3,728)=3,81, \mathrm{p}<, 01]$, Sinav kaygis1 $[(\beta=, 28, \mathrm{p}<.01)$, $\mathrm{t}(3,728)=4,12, \mathrm{p}<, 01]$, ve Öğrenme ve performansla ilgili öz yeterlik $[(\beta=, 12, \mathrm{p}<.01), \mathrm{t}(3,728)$ $=2,22, \mathrm{p}<.01]$ önemli yordayıcısı olduğu görülmektedir. 
Tablo 8. Ortaokul öğrencilerinin Matematik dersi güdüsel inançlarının yordanmasına ilişkin çoklu doğrusal regresyon analizi sonuçları

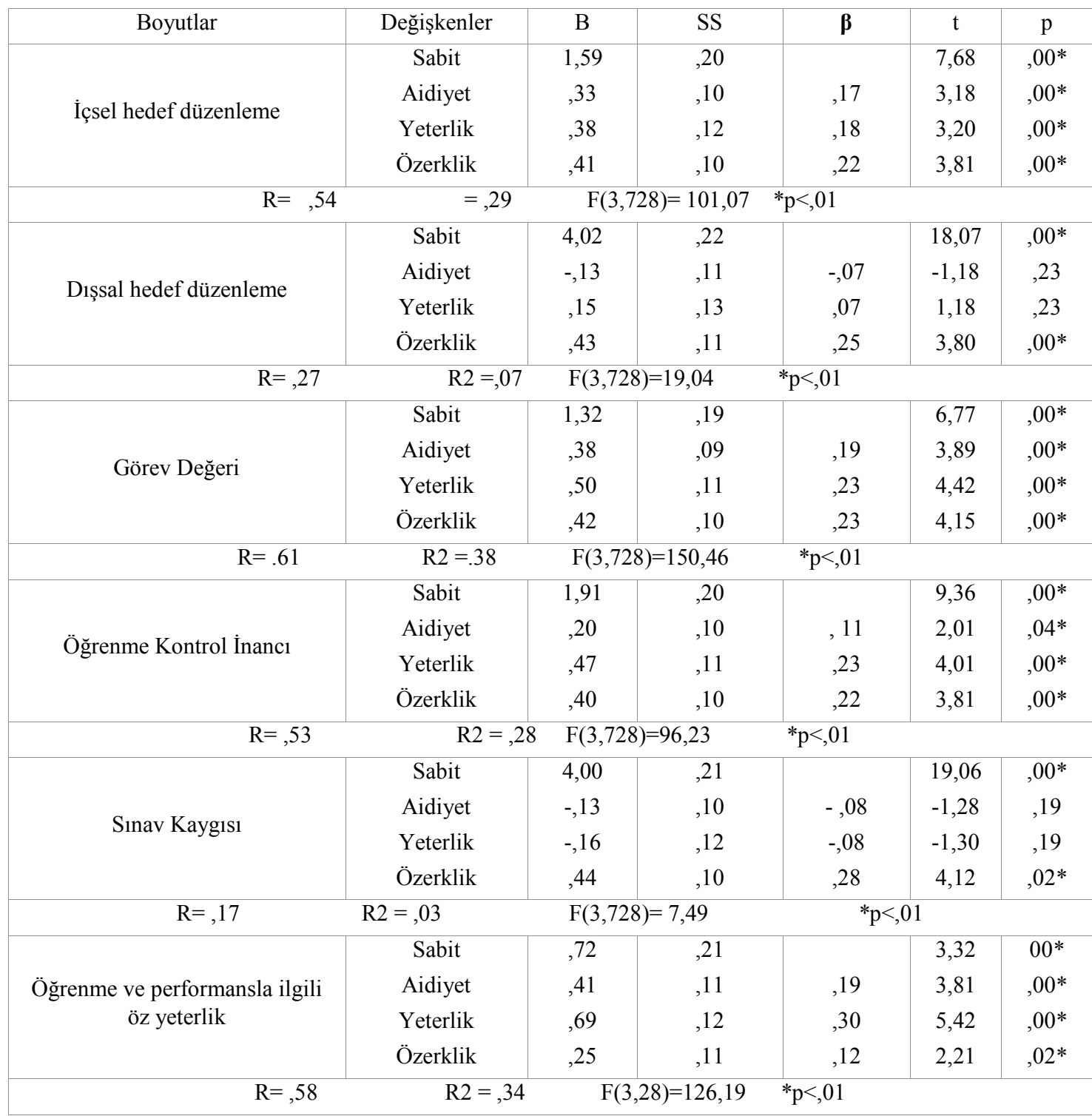

\section{Sonuç ve Tartışma}

Araştırma sonucunda öğrencilerin Matematik dersi güdüsel inançlarının içsel hedef yönelimi, sınav kaygısı ve görev değeri alt boyutlarında kadın öğrencilerin erkeklere göre anlamlı derecede farklılaştığı belirlenmiştir. Ayrıca kadın öğrenciler erkek öğrencilere göre, Matematik öğretmenlerinden algıladıkları aidiyet, ilişki ve özerklik güdüsel desteklerinin daha yüksek olduğu belirlenmiştir. Kadın öğrenciler içsel hedefler belirlemekte, görev değerleri daha yüksek olarak algılamaktadırlar. Ancak aynı zamanda sınav kaygıları da yüksek olmaktadır. Dursun, \& Bindak (2011) 6., 7. ve 8. sınıf öğrencilerinin Matematik kaygılarında cinsiyete göre anlamlı farklılık olmadığı belirlenmiştir. Ergöz (2008) de Matematik dersinde kadınlar ve erkekler arasında, iş değeri, öz-yeterlilik ve sınav kaygısına göre anlamlı bir farka rastlamamıştır. Gülten \& 
Soytürk (2013) ilköğretim 6. sınıf öğrencilerinin geometri özyeterliklerinde cinsiyet değişkenine göre anlamlı bir farklılık olmadığını, Yaman \& Dede (2006) ise kadın ve erkek öğrencilerin Matematik dersi özyeterlik puanlarının farklılık göstermediğini belirlemişlerdir. Benzer bir biçimde Öztürk (2003) kadınlar ve erkekler arasında, içsel amaçlı odaklanma ve dışsal amaçlı odaklanmaya, iş değerine ve kontrol inançlarına göre anlamlı bir ortalama farkına rastlamamıştır. Ancak kadınların Matematik başarısını anlamlı etkileyen, özyeterlik ve dışsal amaçlı odaklanma olmak üzere iki değişken saptanırken; erkeklerin Matematik başarısını anlamlı etkileyen iki değişkenin özyeterlik ve sınav kaygısı olduğu belirlenmiştir. Kılıç (2011) ise Matematik dersine olan güdülenmelerinin cinsiyete göre anlamlı farklılık gösterdiği ve bu farkl1lığında erkek öğrenciler lehine olduğu belirlemiştir. Bulut (2006) 6., 7. ve 8. sinıfta öğrenim gören kadın öğrencilerin erkek öğrencilere göre başarı güdülerinin daha yüksek olduğu belirlenmiştir. Araştırmada cinsiyete ilişkin elde edilen sonucu desteklemeyen ve destekleyen araştırmaların olduğu görülmektedir. Bu çalışmada kadın öğrenciler lehine belirlenen anlamlı farklılık kadın öğrencilerin Matematik öğretmenlerinden aidiyet, ilişki ve özerklik güdüsel desteklerini daha yüksek algılamalarından kaynaklanmış olabilir.

Araştırmada öğrencilerin sınav kaygısı dışında sınıf düzeyleri arttıkça güdülenme puanlarının ve Matematik öğretmenlerinden algıladıkları güdüsel desteğin düştüğü belirlenmiştir. Araştırmada ulaşılan bu sonuç alanyazınla paraleldir. Yaman \& Dede (2006) sınıf düzeyi yükseldikçe Matematik dersine yönelik özyeterliğin düştüğünü belirlemişlerdir. Kılıç-Çakmak et al. (2008) çalışmalarında Matematik, Fen, Türkçe ve Sosyal Bilgiler derslerinde 6. sinıftan 11. sınıfa öğrencilerin güdülenme faktörleriyle ilgili değişimleri incelendiğinde genel olarak sınıf düzeyi yükseldikçe güdülenme düzeylerinin düştüğünü belirlemişlerdir.

Araştırma da başarı notları yüksek olan öğrencilerin güdülenme puanlarının ve Matematik öğretmenlerinden algıladıkları güdüsel desteğin daha yüksek olduğu belirlenmiştir. Alanyazın incelendiğinde bu sonucu destekleyen bulguların olduğu görülmektedir. Bulut (2006) Matematik başarıları yüksek olan öğrencilerin düşük olanlara göre başarı güdülerinin daha yüksek olduğu belirlenmiştir. Kılıç (2011) öğrencilerin Matematik notları ile Matematik dersine yönelik güdülenmeleri arasında pozitif ve orta düzeyde bir ilişki bulunmuştur. Yaman ve Dede (2006)'nin çalışmalarında Matematik başarıları yükseldikçe öğrencilerin özyeterliklerinin yüksek olduğunu belirlemişlerdir. Gülten \& Soytürk (2013) Matematik başarı notları yüksek olan öğrencilerin geometri özyeterliklerinin daha yüksek olduğu belirlemiştir. Araştırmalar Matematik kaygısının Matematik başarısını düşürdüğünü göstermektedir (Dursun \& Bindak, 2011). Derse güdülü olan öğrenci daha başarılı olmakta, derse daha fazla katılmakta, daha olumlu tutum geliştirmekte, özyeterlik inançları daha yüksek olmaktadır. Böylelikle öğrencilerin kendi yeterliliklerini daha olumlu hissetmelerine, aidiyet duyguları ve özerk güdülerinin gelişmesini sağlamaktadır. $\mathrm{Bu}$ durum ayrıca öğrencilerin öğretmenlerinden daha fazla güdüsel destek almalarına da yol açmaktadır (Skinner \& Pitzer 2012; Skinner et al. 2008).

Araştırmada Matematik öğretmenlerinin güdüsel desteklerine ilişkin algıları ile Matematik dersi güdüsel inançları arasında İçsel hedef düzenlemeleri, Görev değeri, Öğrenme kontrol inancı ile Öğrenme ve performansla ilgili öz yeterlik inançları pozitif yönde orta düzeyde önemli ilişki olduğu bulunmuştur. Sınav kaygısı ve Dışsal hedef düzenleme boyutlarında ise ilişki düşüktür. Vanteenkiste et al. (2012) öğretmenlerinden yüksek özerklik desteği algılayan öğrencilerin güdülerinin yüksek olduğu, sınav kaygılarının ise düşük olduğunu belirlemişlerdir. Araştırmada öğrencilerin Matematik öğretmenlerinin aidiyet ve yeterlik desteğinin öğrencilerin İçsel hedef düzenlemelerinin, Görev değeri, Öğrenme kontrol inancı ile Öğrenme ve performansla ilgili öz yeterlik inancının önemli yordayıcısı olduğu bulgusuna ulaşılmıştır. Öğrencilerin Matematik öğretmenlerinden algıladıkları Özerklik desteğinin ise İçsel hedef düzenleme, Dışsal hedef düzenleme, Görev değeri, Öğrenme Kontrol İnancı, Sınav Kaygısı ile Öğrenme ve 
performansla ilgili öz yeterlik inançlarının önemli yordayıcısı olduğu belirlenmiştir. Bu sonuçlara göre öğrencilerin Matematik öğretmenlerinin güdüsel desteklerine ilişkin algılarının Matematik dersine ilişkin güdüsel inançarının önemli yordayıcısı olduğu belirlenmiştir. Diseth \& Samdal (2014) öğrencilerin öğretmenlerinden algıladıkları özerklik desteklerinin hedef yönelimini, Mıh \& Mıh (2013) akademik özyeterliği yordadığını belirlemişlerdir. Skinner et al. (2008) öğrencilerin öğretmenlerinin güdüsel desteklerinin öğrencilerin derse karşı duyulan s1kılma, hayal kırıklığı gibi hoşnutsuzluğun azalmasını yordadığını saptamışlardır. Algılanan kontrol ise kaygıyı artmasında önemli bir yordayıcı olarak bulunmuştur. Reeve et al. (2004) özerklik destekleyici öğretmenlerin öğrencilerinin derse katılımlarının daha fazla olduğunu göstermiştir. Yıldırım (2000) Matematik, Türkçe, Fizik, Kimya ve Biyoloji derslerinde 10. s1nıfta öğrenim gören öğrencilerin akademik başarısını öğretmenlerinden ve ailelerinde algıladıkları destek, başarısını olumlu yönde; yalnızlık ve sınav kaygısı ise olumsuz yönde ve anlamlı olarak yodadığını belirlemiştir. Benzer bir biçimde Yıldırım \& Ergene (2003) 11. sınıf öğrencilerinin öğretmenlerinden aldıkları desteğin öğrencilerin sınav kaygısını olumsuz yönde manidar olarak yordadığını belirlemişlerdir.

Ulaşılan sonuçlar özbelirleme kuramında belirtilen temel gereksinimlerin karşılanması öğrencinin güdülenmesini artırabileceği görüşünü desteklemektedir. Yapılan çalışmada ulaşılan sonuçlar öğrencilerin temel gereksinimleri olan özerklik, yetkinlik ve ilişki desteğinin sınıfta öğretmenler tarafından karşılanmasının öğrencilerin güdüsel inançlarını yani güdülenme kaynaklarını etkilediği belirlenmiştir. Ulaşılan bu sonuçlara göre; öğretmenlere ve öğretmen adaylarına öğretmen güdüsel desteği ve önemi, güdüsel destekleyici öğretim programlarının düzenlenmesi yararlı olacaktır. Ayrıca bu çalışma da öğretmenlerin güdüsel destekleri öğrencilerin alg1ları yoluyla incelenmiştir. Yapılacak olan diğer çalışmalarda öğretmen, öğrenci algıları ve sınıf içi derslerin video kayıtları ve gözlemlerle birlikte ele alınarak değerlendirilmesi yararlı olacaktır. Bu çalışma ortaokul 6., 7. ve 8. sınıflarda Matematik dersi kapsamında gerçekleştirilmiştir. Başka konu alanı ve sınıflarda yapılması yararlı olacaktır. 


\section{KAYNAKÇA}

Açıkgöz K. Ü. (2012). Etkili Öğrenme ve Öğretme. İstanbul 2012.

Akın A. \& Çetin B. (2007). "Başarı Yönelimleri Ölceği: Geçerlik ve Güvenirlik Çalışması". Eğitim Araştırmaları Dergisi 26 (2007) 1-12.

Aktan S. \& Tezci E. (2013). "Matematik Motivasyon Ölçeğinin (MMÖ) Geçerlik ve Güvenirlik Çalışması". International Journal of Social Science 6/4 (2013) 57-77.

Ames C. (1992). "Goals, Structures and Student Motivation". Journal of Educational Psychology 84/3 (1992) 261-271.

Bandura A. (1994). "Self-Efficacy”. Ed. V. S. Ramachaudran. Encyclopedia of Human Behavior (1994) 7181. New York.

Bulut S. (2006). İlkögrretim II. Kademe Öğrencilerinin Matematik Dersinde Kullandlkları Öğrenme Stratejileri ve Başarı Güdüleri. Yayınlanmamış Yüksek Lisans Tezi. Trakya Üniversitesi, Sosyal Bilimler Enstitüsü. Edirne 2006.

Büyüköztürk Ş., Akgün Ö. A., Özkahveci Ö. \& Demirel F. (2004). “The Validity And Reliability Study of The Turkish Version of the Motivated Strategies for Learning Questionnaire". Kuram ve Uygulamada Eğitim Bilimleri 4/2 (2004) 231-239.

Çetin B. \& Akın A. (2009). "An Investigation of The Relationship Between Achievement Goal Orientations and the Use of Stress Coping Strategies with Canonical Correlation". International Journal of Human Sciences 6/1 (2009) 242-255.

Deci E. L., Vallerand R. J., Pelletier L. G. \& Ryan M. R. (1991). "Motivation and Education: The SelfDetermination Perspective". Educational Psychologist 26/3-4 (1991) 325-346. DOI:10.1080/00461520.1991.9653137.

Diseth A. \& Samdal O. (2014). "Autonomy Support and Achievement Goals as Predictors of Perceived School Performance and Life Satisfaction in the Transition Between Lower and Upper Secondary School". Soc Psychol Educ. DOI: 10.1007/s11218-013-9244-4.

Dursun Ş. \& Bindak R. (2011). "Illköğretim II. Kademe Öğrencilerinin Matematik Kaygılarının Incelenmesi". Cumhuriyet Üniversitesi Sosyal Bilimler Dergisi 35/1 (2011) 18-21.

Elliot A. J. (1999). "Aproach and Avoidance Motivation and Achievement Goals". Educational Psychologist 34/3 (1999) 169-189.

Ergöz G. (2008). Investigation of Self-Regulated Learning and Motivational Beliefs in Mathematics Achievement. Yayınlanmamış Yüksek Lisans Tezi. Orta Doğu Teknik Üniversitesi, Fen Bilimleri Enstitüsü. Ankara 2008.

Fortier M. S., Vollerand R. J. \& Gay F. (1995). "Academic Motivation and School Performance: Toward A Structural Model". Contemporary Educational Psychology 20 (1995) 257-274. DOI: 10.1006/ceps. 1995.1017.

Gülten Ç. D. \& Soytürk İ. (2013) "İlköğretim 6. Sınıf Öğrencilerinin Geometri Özyeterliklerinin Akademik Başarı Not Ortalamaları İle İlişkisi”. Mehmet Akif Ersoy Üniversitesi Eğitim Fakültesi Dergisi 13/25 (2013) 55-70.

Güvenç E. \& Güvenç H. (2014). "İlköğretim Matematik İle Fen ve Teknoloji Öğretmenlerinin Sınıf Yönetim Biçemleri ve Özerklik Desteği Algıları”. NWSA-Education Sciences 9/3 (2014) 311-322. DOI:10.12739/NWSA.2014.9.3.1C0620.

Güvenç H. (2011). "Sınıf Öğretmenlerinin Özerklik Destekleri ve Mesleki Özyeterlik Algıları”. Kuram ve Uygulamada Ĕ̈itim Yönetimi 17/1 (2011) 99-116.

Güvenç H. (2015). "The Relationship between Teachers' Motivational Support and Engagement versus Disaffection”. Educational Sciences: Theory \& Practice 15/3 (2015) 647-657. DOI:10.12738/estp. 2015.3.2662.

Jungert T. \& Koestner R. (2015). "Science Adjustment, Parental and Teacher Autonomy Support and The Cognitive Orientation of Science Students". Educational Psychology 35/3 (2015) 361-376. DOI: $10.1080 / 01443410.2013 .828826$

Karadeniz Ş., Büyüköztürk Ş., Akgün Ö. E., Kılıç-Çakmak E. \& Demirel F. (2008). "The Turkish 
Adaptation Study of Motivated Strategies for Learning Questionnaire (MSLQ) For 12-18 Year Old Children: Results of Confirmatory Factor Analysis". The Turkish Online Journal of Educational Technology 7/4 (2008) 108-117.

Karasar N. (2009). Bilimsel Araştırma Yöntemi. Ankara 2009.

Kılıç A. S. (2011). İlköğretim Ikinci Kademe Öğrencilerinin Genel Başarılarl, Matematik Başarıları, Matematik Dersine Yönelik Tutumları, Güdülenmeleri ve Matematik Kayglları Arasındaki İlişki. Yayınlanmamış Yüksek Lisans Tezi. Gazi Üniversitesi, Eğitim Bilimleri Enstitüsü. Ankara 2011.

Kılıç Ç. \& Tanrıseven I. (2012). “Öz-Düzenleme Stratejileri ve Motivasyonel İnançlar ile Standart Olmayan Sözel Problem Çözme Arasındaki İlişkiler”. Abant İzzet Baysal Üniversitesi Eğitim Fakültesi Dergisi 12/1 (2012) 167-180.

Kılıç-Çakmak E., Akgün Ö. E., Karadeniz Ş., Büyüköztürk Ş. \& Demirel F. (2008). "İlköğretim İkinci Kademe ve Lise Öğrencilerinin Ders ve Sınıf Düzeylerine Göre Öğrenme Stratejileri ve Güdülenme Düzeylerinin Belirlenmesi”. Uluslararası Ínsan Bilimleri Dergisi 5/1 (2008) 1-27.

Mih V. \& Mih C. (2013) "Perceived Autonomy-Supportive Teaching, Academic Self-Perceptions and Engagement in Learning: Toward a Process Model of Academic Achievement". Cognition, Brain, Behavior An Interdisciplinary Journal 17/4 (2013) 289-313.

Niemiec C. P. \& Ryan R. M. (2009). "Autonomy, Competence and Relatedness in the Classroom: Applying Self-Determination Theory to Educational Practice". Theory and Research in Education 133 (2009) 133-144. DOI: 10.1177/1477878509104318.

Oğuz A. (2013). “Öğretmenlerin Öğrenen Özerkliğinin Desteklenmesine İlişkin Görüşleri”. Uluslararası Insan Bilimleri Dergisi 10/1(2013) 1273-1297.

Özkal N. (2013a). "The Relationship Between Achievement Goal Orientations and Self Regulated Learning Strategies of Secondary School Students in Social Studies Courses". International Journal of Academic Research Part B 5/3 (2013) 387-394. DOI: 10.7813/2075-4124.2013/5-3/B.59.

Özkal N. (2013b). "Sosyal Bilgilere İlişkin İçsel ve Dışsal Güdülerin Özyeterlik ve Başarı Yönelimlerine Göre Yordanması”. Mehmet Akif Ersoy Üniversitesi Ĕ̆itim Fakültesi Dergisi 13/27 (2013) 98-117.

Özkal N. \& Demirkol A. (2014). “Öğrenen Özerkliğinin Desteklenmesinin Gerekliliğine ve Sergilenmesine Ilişkin Öğretmen Görüşleri“. NWSA-Education Sciences 9/3 (2014) 293-310. DOI: 0.12739/NWSA.2014.9.3.1C0619.

Öztürk B. (2003). Relationships Among Self-Regulated Learning Components, Motivational Beliefs and Mathematics Achievement. Yayınmlanmamış Yüksek Lisans Tezi. Orta Doğu Teknik Üniversitesi. Ankara 2003.

Pintrich P. R. (1999). "The Role of Motivation in Promoting and Sustaining Self Regulated Learning". International Journal of Educational Research 31 (1999) 459-470.

Reeve J., Vansteenkiste M., Assor A., Ahmad I., Cheon S. H., Jang H., Kaplan H., Moss J., Olaussen B. S. \& Wang J. (2013). "The Beliefs That Underlie Autonomy-Supportive and Controlling Teaching: A Multinational Investigation”. Motivation and Emotion 38 (2013) 93-110. DOI: 10.1007/s11031-0139367-0.

Reeve J. (2009). "Why Teachers Adopt a Controlling Motivating Style Toward Students and How They Can Become More Autonomy Supportive". Educational Psychologist 44/3 (2009) 159-175. DOI: 10.1080/00461520903028990.

Reeve J. (2006). "Teachers as Facilitators: What Autonomy- Supportive Teachers Do and Why Their Students Benefits". The Elementary School Journal 106/3 (2006) 225-236. DOI: 10.1086/501484.

Reeve J., Jang H., Carrell D., Jeon S. \& Barch J. (2004). “Enhancing Students' Engagement by Increasing Teachers' Autonomy Support”. Motivation and Emotion 28/2 (2004) 147-216.

Schunk D. H. (1994). "Self-regulation of Self Effiacy and Attributions in Academic Settings". Ed. D. H. Schunk, B. J. Zimmerman. Self Regulation of Learning and Performence Issues and Educational Aplication (1994) 76-99. Lawrence Erlbaum.

Seniye V. (2007). Teachers and Students Perceptions of Teacher Motivational Behavior. Yayınlanmamış Yüksek Lisans Tezi. İhsan Doğramacı Bilkent Üniversitesi, Eğitim Bilimleri. Ankara 2007.

Skinner E. \& Pitzer J. R. (2012). "Developmental Dynamics of Student Engagement, Coping, and 
Everyday Resilience". Ed. S. L. Christenson et al. Handbook of Research on Student Engagement (2012) 21-44. DOI: 10.1007/978-1-4614-2018-7_2.

Skinner E., Furrer C., Marchand G. \& Kindermann T. (2008) "Engagement and Disaffection in the Classroom: Part of a Larger Motivational Dynamic?". Journal of Educational Psychology 100/4 (2008) 765-781. DOI: $10.1037 / \mathrm{a} 0012840$.

Sünbül A. M., Kesici Ş. \& Bozgeyikli H. (2003). "Öğretmenlerin Psikolojik İhtiyaçları, Öğrencileri Motive ve Kontrol Etme Düzeyleri”. Selçuk Üniversitesi Araştırma Fonu, Proje No: 2002-236.

Şan İ. (2013). "Seviye Belirleme Sınavlarının Matematik Öğretiminde Karşılaşılan Sorunlara Etkisine İlişkin Öğretmen Görüşleri”. Turkish Studies 8/6 (2013) 697-706.

Tahiroğlu M. \& Çakır S. (2014). "İlkokul 4. Sınıflara Yönelik Matematik Motivasyon Ölçeğinin Geliştirilmesi”. Ahi Evran Üniversitesi Kırşehir Eğitim Fakültesi Dergisi (KEFAD) 15/3 (2014) 29-48.

Tschannen-Moran M. \& Woolfolk-Hoy A. (2001). "Teacher Efficacy: Capturing an Elusive Construct". Teaching and Teacher Education 17 (2001) 783-805.

Türk Psikiyatri Derneği (2015). Kaynak: http://www.psikiyatri.org.tr/pagepublic.aspx?menu=42 Erişim Tarihi: 18 Şubat 2015.

Üredi I. \& Üredi L. (2005). “İlköğretim 8. Sınıf Öğrencilerinin Öz-Düzenleme Stratejileri ve Motivasyonel İnançlarının Matematik Başarısını Yordama Gücü”. Mersin Üniversitesi Eğitim Fakültesi Dergisi 1/2 (2005) 250-260.

Yaman S. \& Dede Y. (2006). "İlköğretim Öğrencilerinin Matematik Dersine Yönelik Özyeterlik İnanç Düzeyleri Üzerine Bir Çalışma”. Türkiye Sosyal Araştırmalar Dergisi 10/1-2 (2006) 109-119.

Yıldııı İ. (2000). "Akademik Başarının Yordayıcısı Olarak Yalnızlık, Sınav Kaygısı ve Sosyal Destek". Hacettepe Üniversitesi Eğitim Fakültesi Dergisi 18 (2000) 167-176.

Yıldırım İ. \& Ergene T. (2003). "Lise Son Sınıf Öğrencilerinin Akademik Başarılarının Yordayıcısı Olarak Sınav Kaygısı Boyun Eğici Davranışlar ve Sosyal Destek”. Hacettepe Üniversitesi Eğitim Fakültesi Dergisi 25 (2003) 224-234.

Yılmaz Ç. (2011). 6, 7 ve 8. Sinıf Öğrencilerinin Matematik Güdüsü, Kaygısl, Öz Yeterlik Inancı ve Öz Kavramı Ile Matematik Dersine Yönelik Tutumları Arasındaki Ilişkiler: Şereflikoçhisar Örneği. Yayınlanmamış Yüksek Lisans Tezi. Ankara Üniversitesi, Eğitim Bilimleri Enstitüsü. Ankara 2011.

Yücel C., Karadağ E. \& Turan S. (2013). TIMSS 2011 Ulusal Ön Değerlendirme Raporu. Eskişehir Osmangazi Üniversitesi Eğitim Fakültesi Eğitimde Politika Analizi Raporlar Serisi I.

Vanteenkiste M., Sierens E., Goossens L., Soenens B., Dochy F. M., Mouratidis A., Aelterman N., Haerens L. \& Beyers W. (2012). "Identifying Configurations of Perceived Teacher Autonomy Support and Structure: Associations With Self- Regulated Learning, Motivation and Problem Behavior". Learning and Instruction 22 (2012) 431-439. DOI: 10.1016/j.Learn. And Instruc.2012.04.002.

Zimmerman B. J. (2000). "Self-Efficacy: An Essential Motive to Learn". Contemporary Educational Psychology 25 (2000) 82-91. 